\title{
THE ROLE OF PLASMA FREE FATTY ACIDS IN DEVELOPMENT OF FATTY LIVER
}

\author{
By EUGENE B. FEIGELSON, $\dagger$ WILLIAM W. PFAFF, ARTHUR KARMEN \\ AND DANIEL STEINBERG
}

\author{
(From the National Heart Institute, National Institutes of Health, U. S. Public Health Service, \\ Bethesda, Md.)
}

(Submitted for publication June 5, 1961 ; accepted August 17, 1961)

The accumulation of fat in the liver under many diverse experimental conditions has frequently been used as an index of fat mobilization from adipose tissue (1-6). In recent years, it has become clear that the free fatty acids (FFA) of the plasma represent a major transport form for mobilization of lipid from adipose tissue $(7,8)$ and methods are now generally available for measurement of this important plasma lipid component $(7,9,10)$. Therefore, it is now possible to examine more directly this inferred relationship between mobilization of fat and the development of fatty liver. The present experiments were designed to determine whether increasing the rate of mobilization of fatty acids from the periphery in normal animals might lead to development of fatty liver. Epinephrine causes an immediate and marked increase in the rate of release of FFA from adipose tissue in vitro (11) and in vivo (12), and norepinephrine acts similarly $(13,14)$. Because the FFA response to norepinephrine is smoother and more sustained than the response to epinephrine (13), the former has been used in most of these experiments.

\section{METHODS AND EXPERIMENTAL PROCEDURE}

Experiments were performed on male mongrel dogs weighing 8 to $15 \mathrm{~kg}$, maintained for 1 to 3 weeks on a diet of canned meat ${ }^{1}$ which was offered each morning for a period of 4 hours. Following a 24-hour fast, the animals, anesthetized with sodium pentothal (thiopental), received via the femoral vein an 8-hour infusion of norepinephrine 2 in saline ( 1 to $2 \mu \mathrm{g}$ per $\mathrm{kg}$ per minute) while the control animals received only saline. The infusion was delivered by a Bowman pump at a constant rate of $1 \mathrm{ml}$ per minute. Before starting the infusion, liver biopsies ( 1 to $2 \mathrm{~g}$ ) were obtained through an abdominal incision which was closed before the infusion was begun.

\footnotetext{
${ }^{1}$ Red Heart Dog Food, John Morrel and Co.

2 Parke, Davis and Co.
}

Portal vein infusions were administered by way of a small polyethylene catheter introduced into a splenic vein and threaded up to the portal vein at the time of laparotomy. At the end of the 8-hour infusion, a second liver biopsy was obtained through the same incision which was reopened for this purpose. In one experiment, serial liver biopsies were obtained at $0,2,4$ and 8 hours during the course of a norepinephrine infusion. Serial blood samples were taken throughout each infusion. All blood samples were drawn from the femoral vein into dry syringes, transferred to heparin-containing tubes, promptly chilled, and kept at $4^{\circ} \mathrm{C}$ until analytical procedures were started. Plasma FFA were determined by the method of Dole (9). All biopsies were analyzed for total cholesterol (15), phospholipids (16), and total lipids (17), and examined histologically for fat using an Oil Red O stain. Triglycerides were calculated by the Bragdon method (17). The portions of the liver biopsies used for lipid analysis were homogenized in acetone-ethanol $(1: 1, \mathrm{vol} / \mathrm{vol})$ and centrifuged. One aliquot of the supernatant was taken for cholesterol determination and the remainder was taken to dryness under nitrogen. The residue was taken up in chloroformmethanol (2:1), water was added to separate the two phases, and aliquots of the chloroform phase were taken for determination of phospholipids and total lipids. Blood glucose was measured colorimetrically by the SomogyiNelson method (18).

Liver lipids were fractionated into subclasses using a silicic acid column according to Borgstrom (19). The neutral lipids as a group were eluted with chloroform and the phospholipids with methanol. The lipids in the chloroform eluate were then applied to silicic acid-treated paper on which the cholesterol esters and glycerides were separated by using 99 per cent iso-octane, 1 per cent acetic anhydride as solvent (20). The lipid spots on the paper were identified by staining with a spray of 0.04 per cent Rhodamine $\mathrm{B}$ in methanol. Then the spots were cut out and eluted with chloroform-methanol (2:1), which was then evaporated to dryness in small glass tubes. One $\mathrm{ml}$ of methanol containing 2 per cent $\mathrm{H}_{2} \mathrm{SO}_{4}$ ( $\mathrm{vol} / \mathrm{vol}$ ) was then added to each tube, the tubes were sealed, and the mixtures were heated at $65^{\circ} \mathrm{C}$ overnight. One $\mathrm{ml}$ of water was then added to each tube and the methyl esters were extracted into petroleum ether. The petroleum ether extracts were concentrated and aliquots were analyzed by gas-liquid chromatography. The column used was a $\mathrm{U}$-shaped glass column, $4 \mathrm{~mm}$ I.D., 6 


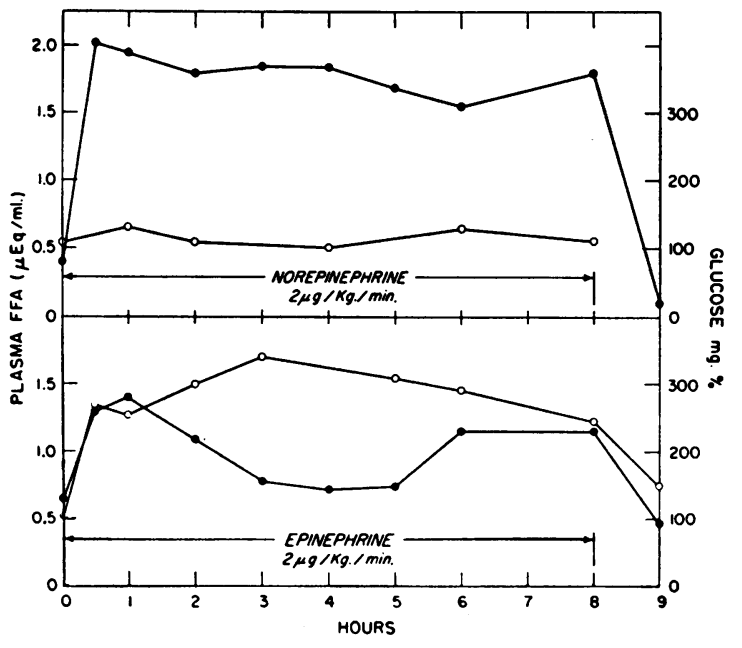

Fig. 1. Plasma FFA (-—) AND glucose (O-O) RESPONSES TO CONTINUOUS FEMORAL VEIN INFUSION OF NOREPINEPHRINE (ABOVE) AND EPINEPHRINE (BELOW). Same animal used for both studies.

feet long, packed with Chromosorb W (Johns Manville) on which a coating of ethylene glycol-adipate polyester, 10 per cent (wt/wt), had been applied. The analysis was performed at $190^{\circ} \mathrm{C}$. The detector used was a modification of that described by Lovelock (21), the response of which had been calibrated for quantitative accuracy.

\section{RESULTS}

Comparative effects of epinephrine and norepinephrine on plasma FFA and glucose levels during an 8-hour infusion. Figure 1 represents the changes in plasma FFA and glucose levels during norepinephrine infusion (top half), and at a later date, and in the same dog, during epinephrine infusion (bottom half). The FFA response to norepinephrine was sustained at high levels throughout the 8-hour infusion, dropping precipitously when the infusion was terminated. The FFA response to epinephrine was prompt and marked but the maximal levels reached were not as high as those seen with norepinephrine. Despite continued infusion of epinephrine at the same rate, the FFA level fell to values not far above the control level but then rose again later in the experiment. These changes in FFA level appeared to bear a reciprocal relation to changes in blood glucose levels. Norepinephrine has insignificant glycogenolytic properties compared with epinephrine (22), and no rise in blood glucose is seen with the former. Norepinephrine was therefore chosen for the fol- lowing experiments in which sustained FFA levels were desired.

Effect of an 8-hour infusion of norepinephrine on liver lipids. In Figure 2 the effect of an 8-hour infusion of norepinephrine on liver triglyceride concentration is illustrated. There was a progressive rise in liver triglyceride content throughout the infusion from an initial level of 4 to $5 \mathrm{mg}$ per $\mathrm{g}$ liver to an 8-hour concentration of $33 \mathrm{mg}$ per g. Associated with the increase in triglycerides was a marked elevation of the plasma concentration of FFA which continued until the infusion was terminated. The microscopic appearance of the liver is shown in Figure 3, in which a progressive rise in stainable fat is seen with a striking fatty infiltration by 8 hours.

Seven experiments were carried out in which the changes in plasma FFA concentration and the changes in liver lipid concentrations were measured over the course of an 8-hour infusion of norepinephrine. The FFA responses are shown in Figure $4(\mathrm{E}-\mathrm{K})$, along with the curves for FFA concentration in four control animals (A-D) receiving intravenous saline only. The corresponding changes in liver lipids are tabulated in Table I. All experimental animals (E-K) had a marked and sustained elevation of plasma FFA for the duration of the infusion, which was associated with increases in liver triglyceride as great as tenfold over the 8-hour period (mean increase, 773 per cent). The plasma FFA levels of the control animals (A-D) remained low and there was little or no change in liver triglyceride (mean increase, 39 per cent). The concentrations of liver cholesterol and phospholipids showed

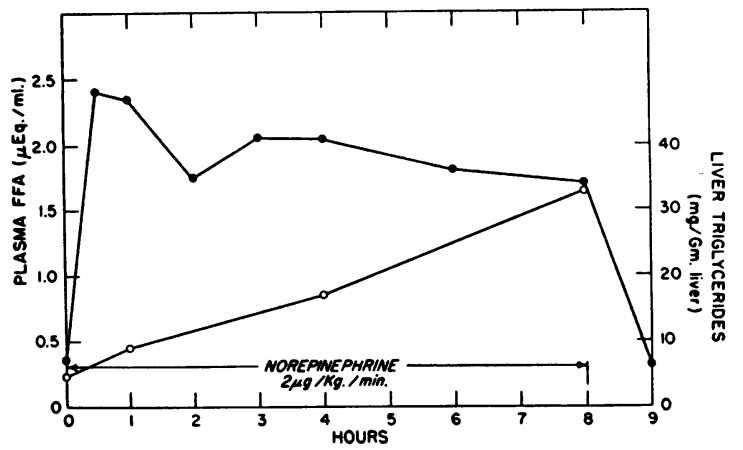

Fig. 2. Plasma FFA (-—) AND LIVER TRIGLYCERIDE ( $O-O$ ) RESPONSES TO CONTINUOUS FEMORAL VEIN INFUSION OF NOREPINEPHRINE. 


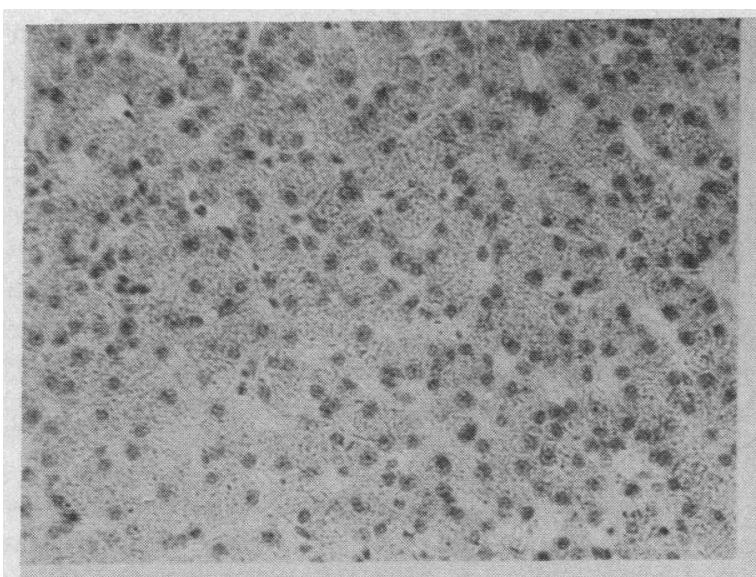

O hours

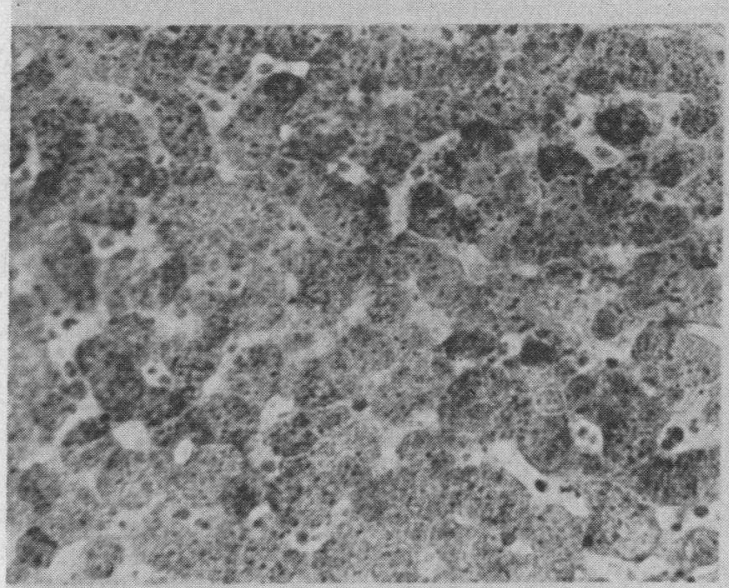

4 hours

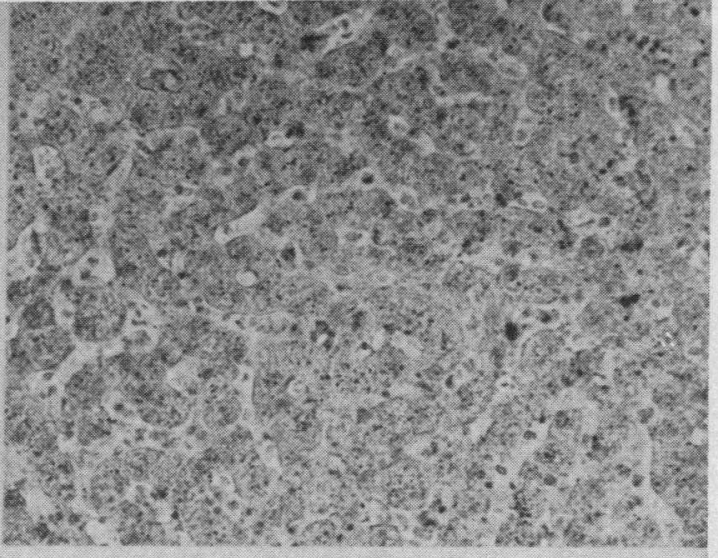

I hour

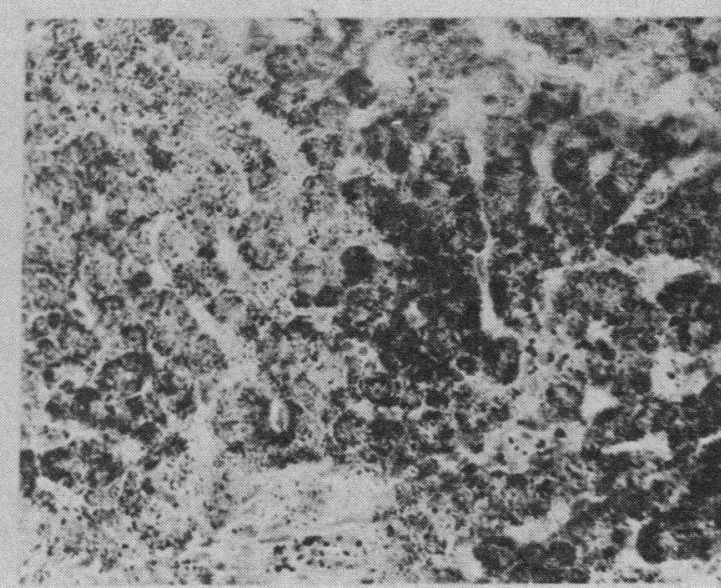

8 hours

Fig. 3. Histologic SECTIONS OF LIVER BIOPSIES TAKEN DURING THE COURSE OF THE EXPERIMENT ILLUSTRATED IN Figure 2 at 0, 1, 4 and 8 hours. The lipid staining material appears black in this reproduction (stained with Oil Red O).

very small changes. These were consistently positive over the 8 -hour period, but the mean changes were not significantly different in control and experimental groups. The mean change for total cholesterol in the control group was +8 per cent and in the experimental group +12.4 per cent. Mean phospholipid change in the control group was +10.3 per cent and in the experimental group +6.9 per cent. Thus, norepinephrine did not appear to have an influence on these small changes, while it markedly affected triglyceride concentrations. Comparable increases in plasma FFA and liver triglyceride were achieved with the two concentrations of norepinephrine infused.

The changes in plasma total cholesterol levels during and after systemic infusion of norepinephrine were variable in the anesthetized, operated animals. In five experiments, changes in the plasma cholesterol levels 6 hours after the start of the infusion varied from +13 to -16 per cent, with a mean change of +1 per cent. In three of these animals there were significant increases $(12,21$ and 24 per cent, respectively) at some time in the period between 4 and 8 hours after the start of the infusion. Plasma cholesterol levels were determined at 24 hours (16 hours after termination of the infusion) in four animals. Two showed no rise; two showed elevations of 17 and 24 per cent, respectively. The variability in these responses may be due to the anesthetic or 


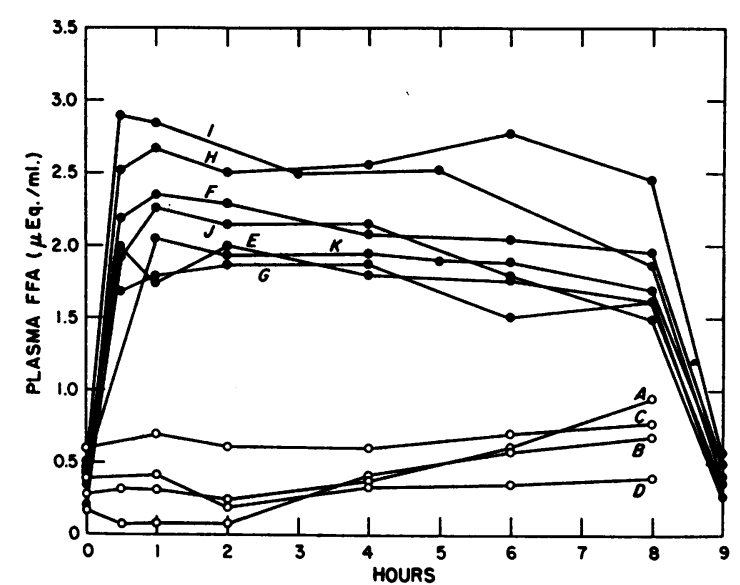

Fig. 4. Plasma fFA curves of seven animals (-—) RECEIVING CONTINUOUS 8-HOUR INFUSIONS OF NOREPINEPHRINE AND OF FOUR CONTROL ANIMALS (O-O) RECEIVING SALINE. The letters on each curve correspond to the same letters in Table I, which shows the corresponding liver lipid changes.

operative procedures, or both, including the handling of the liver. Two studies were done with an anesthetized dog not subjected to surgical bi- opsy until the end of the 8-hour infusion, the first using epinephrine, the second using norepinephrine. On both occasions the serum cholesterol at 8 hours was found to be elevated (35 and 29 per cent above control levels, respectively) and then fell toward normal at 24 hours. The timing of these responses differs notably from that seen when unanesthetized dogs were given epinephrine in oil, in which case there was no elevation at 6 hours but consistent elevations, averaging 28.6 per cent, at 24 hours (23).

Effect on liver lipids of 8-hour norepinephrine infusion into the portal vein. That the liver is a principal site of norepinephrine inactivation is established (24). In Figure 5, the FFA response to norepinephrine infusion ( $1 \mu \mathrm{g}$ per $\mathrm{kg}$ per minute) via the portal vein is seen to be insignificant when compared with the FFA response to the same amount of norepinephrine infused into the femoral vein of the same dog. Failure of the FFA to increase during portal vein infusion was associated with failure of the mean blood pressure to rise sig-

TABLE I

Changes in liver lipid concentrations induced by norepinephrine infusion

\begin{tabular}{|c|c|c|c|c|c|}
\hline Dog & Hour & $\begin{array}{c}\text { Total } \\
\text { cholesterol }\end{array}$ & $\begin{array}{c}\text { Free } \\
\text { cholesterol }\end{array}$ & Phospholipids & Triglycerides \\
\hline \multicolumn{2}{|c|}{ Controls (saline infusion) } & \multicolumn{2}{|c|}{$m g / g$ liver wet wt } & \multicolumn{2}{|c|}{$m g / g$ liver wet wt } \\
\hline A & $\begin{array}{c}0 \\
8 \\
\text { Difference }\end{array}$ & $\begin{array}{l}1.99 \\
2.19 \\
0.20\end{array}$ & $\begin{array}{l}1.77 \\
2.06 \\
0.29\end{array}$ & $\begin{array}{r}27.3 \\
30.6 \\
3.3\end{array}$ & $\begin{array}{l}4.7 \\
8.1 \\
3.4\end{array}$ \\
\hline $\mathrm{B}$ & $\begin{array}{c}0 \\
8 \\
\text { Difference }\end{array}$ & $\begin{array}{l}2.02 \\
2.20 \\
0.08\end{array}$ & $\begin{array}{l}1.89 \\
1.98 \\
0.09\end{array}$ & $\begin{array}{r}27.5 \\
31.6 \\
4.1\end{array}$ & $\begin{array}{l}4.2 \\
5.2 \\
1.0\end{array}$ \\
\hline $\mathrm{C}$ & $\begin{array}{c}0 \\
8 \\
\text { Difference }\end{array}$ & $\begin{array}{l}2.09 \\
2.32 \\
0.23\end{array}$ & $\begin{array}{l}1.88 \\
2.08 \\
0.20\end{array}$ & $\begin{array}{r}30.3 \\
32.8 \\
2.5\end{array}$ & $\begin{array}{l}3.4 \\
4.2 \\
0.8\end{array}$ \\
\hline $\mathrm{D}$ & $\begin{array}{c}0 \\
8 \\
\text { Difference }\end{array}$ & $\begin{array}{l}2.79 \\
3.02 \\
0.23\end{array}$ & $\begin{array}{l}2.41 \\
2.46 \\
0.05\end{array}$ & $\begin{array}{r}33.6 \\
35.6 \\
2.0\end{array}$ & $\begin{array}{r}8.1 \\
11.0 \\
2.9\end{array}$ \\
\hline \multicolumn{6}{|c|}{ Mean increase in triglycerides: $+39 \%$} \\
\hline \multicolumn{6}{|c|}{ Norepinephrine $(1 \mu \mathrm{g} / \mathrm{kg} / \mathrm{min}$ by femoral vein infusion) } \\
\hline $\mathrm{E}$ & $\begin{array}{c}0 \\
8 \\
\text { Difference }\end{array}$ & $\begin{array}{l}2.48 \\
2.55 \\
0.07\end{array}$ & $\begin{array}{l}2.10 \\
2.13 \\
0.03\end{array}$ & $\begin{array}{r}33.5 \\
34.6 \\
1.1\end{array}$ & $\begin{array}{r}7.6 \\
32.0 \\
24.4\end{array}$ \\
\hline $\mathrm{F}$ & $\begin{array}{c}0 \\
8 \\
\text { Difference }\end{array}$ & $\begin{array}{l}2.38 \\
2.71 \\
0.33\end{array}$ & $\begin{array}{l}2.08 \\
2.35 \\
0.27\end{array}$ & $\begin{array}{r}30.8 \\
33.5 \\
2.7\end{array}$ & $\begin{array}{r}3.0 \\
39.0 \\
36.0\end{array}$ \\
\hline G & $\begin{array}{c}0 \\
8 \\
\text { Difference }\end{array}$ & $\begin{array}{l}3.15 \\
3.25 \\
0.10\end{array}$ & $\begin{array}{l}2.90 \\
3.00 \\
0.10\end{array}$ & $\begin{array}{r}34.8 \\
39.2 \\
4.4\end{array}$ & $\begin{array}{r}4.1 \\
40.0 \\
35.9\end{array}$ \\
\hline \multicolumn{6}{|c|}{ Mean increase in triglycerides: $+799 \%$} \\
\hline
\end{tabular}


ROLE OF PLASMA FREE FATTY ACIDS IN DEVELOPMENT OF FATTY LIVER

TABLE I-(Continued)

\begin{tabular}{|c|c|c|c|c|c|}
\hline Dog & Hour & $\begin{array}{c}\text { Total } \\
\text { cholesterol }\end{array}$ & $\begin{array}{c}\text { Free } \\
\text { cholesterol }\end{array}$ & Phospholipids & Triglycerides \\
\hline & & \multicolumn{2}{|c|}{$m g / g$ liver wet $w t$} & \multicolumn{2}{|c|}{$m g / g$ liver wet wt } \\
\hline \multicolumn{6}{|c|}{ Norepinephrine $(2 \mu \mathrm{g} / \mathrm{kg} / \mathrm{min}$ by femoral vein infusion) } \\
\hline $\mathrm{H}$ & $\begin{array}{c}0 \\
8 \\
\text { Difference }\end{array}$ & $\begin{array}{l}2.50 \\
2.99 \\
0.49\end{array}$ & $\begin{array}{l}2.33 \\
2.65 \\
0.32\end{array}$ & $\begin{array}{r}30.6 \\
31.6 \\
1.0\end{array}$ & $\begin{array}{r}3.5 \\
24.0 \\
30.5\end{array}$ \\
\hline I & $\begin{array}{c}\mathbf{0} \\
\stackrel{8}{\text { Difference }}\end{array}$ & $\begin{array}{l}1.94 \\
2.48 \\
0.54\end{array}$ & $\begin{array}{l}1.89 \\
2.22 \\
0.33\end{array}$ & $\begin{array}{r}27.3 \\
30.5 \\
3.2\end{array}$ & $\begin{array}{r}5.3 \\
51.0 \\
45.7\end{array}$ \\
\hline $\mathrm{J}$ & $\begin{array}{c}0 \\
8 \\
\text { Difference }\end{array}$ & $\begin{array}{l}2.05 \\
2.30 \\
0.25\end{array}$ & $\begin{array}{l}1.85 \\
2.10 \\
0.25\end{array}$ & $\begin{array}{r}29.3 \\
30.1 \\
0.8\end{array}$ & $\begin{array}{r}2.5 \\
33.0 \\
30.5\end{array}$ \\
\hline $\mathrm{K}$ & $\begin{array}{c}0 \\
8 \\
\text { Difference }\end{array}$ & $\begin{array}{l}2.92 \\
3.13 \\
0.21\end{array}$ & $\begin{array}{l}2.63 \\
2.65 \\
0.02\end{array}$ & $\begin{array}{r}29.9 \\
31.7 \\
1.8\end{array}$ & $\begin{array}{l}18.0 \\
29.0 \\
11.0\end{array}$ \\
\hline \multicolumn{6}{|c|}{ Mean increase in triglycerides: $+754 \%$} \\
\hline \multicolumn{6}{|c|}{ Norepinephrine ( $1 \mu \mathrm{g} / \mathrm{kg} / \mathrm{min}$ by portal vein infusion) } \\
\hline $\mathbf{L}$ & $\begin{array}{c}0 \\
8 \\
\text { Difference }\end{array}$ & $\begin{array}{l}2.73 \\
3.02 \\
0.29\end{array}$ & $\begin{array}{l}2.17 \\
2.19 \\
0.02\end{array}$ & $\begin{array}{r}30.0 \\
31.0 \\
1.0\end{array}$ & $\begin{array}{l}9.0 \\
9.5 \\
0.5\end{array}$ \\
\hline M & $\begin{array}{c}0 \\
8 \\
\text { Difference }\end{array}$ & $\begin{array}{l}2.45 \\
2.84 \\
0.39\end{array}$ & $\begin{array}{l}2.18 \\
2.51 \\
0.33\end{array}$ & $\begin{array}{r}31.1 \\
34.9 \\
3.8\end{array}$ & $\begin{array}{l}3.4 \\
3.4 \\
0.0\end{array}$ \\
\hline \multicolumn{6}{|c|}{ Mean increase in triglycerides: $+2.8 \%$} \\
\hline \multicolumn{6}{|c|}{ Norepinephrine $(2 \mu \mathrm{g} / \mathrm{kg} / \mathrm{min}$ by portal vein infusion) } \\
\hline $\mathrm{N}$ & $\begin{array}{c}0 \\
8 \\
\text { Difference }\end{array}$ & $\begin{array}{l}3.04 \\
3.23 \\
0.19\end{array}$ & $\begin{array}{l}2.33 \\
2.42 \\
0.09\end{array}$ & $\begin{array}{r}30.9 \\
31.6 \\
0.7\end{array}$ & $\begin{array}{r}13.0 \\
14.0 \\
1.0\end{array}$ \\
\hline $\mathrm{O}$ & $\begin{array}{c}0 \\
8 \\
\text { Difference }\end{array}$ & $\begin{array}{l}2.86 \\
3.19 \\
0.33\end{array}$ & $\begin{array}{l}2.18 \\
2.25 \\
0.07\end{array}$ & $\begin{array}{r}31.3 \\
31.4 \\
0.1\end{array}$ & $\begin{array}{l}18.0 \\
28.0 \\
10.0\end{array}$ \\
\hline \multicolumn{6}{|c|}{ Mean increase in triglycerides: $+32 \%$} \\
\hline
\end{tabular}

nificantly. When systemic infusion was started, both blood pressure and FFA levels rose. Figure 6 illustrates the differences in plasma FFA levels between dogs receiving an 8-hour norepinephrine infusion at a rate of $1 \mu \mathrm{g}$ per $\mathrm{kg}$ per minute systemically and dogs receiving norepinephrine at the same rate via the portal vein. At the end of 8 hours, after liver biopsies were taken, the portal vein infusions were changed to systemic infusion to demonstrate that the dogs were capable of responding with an FFA increase. The liver lipid changes resulting from the infusions depicted in Figure 6 are included in Table I. There were no changes in the dogs receiving the portal vein infusions ( $L, M)$, but the triglyceride changes associated with the systemic infusions are great $(E, G)$. In two additional experiments, the rate of norepinephrine infusion into the portal vein was doubled ( $2 \mu \mathrm{g}$ per $\mathrm{kg}$ per minute), and in these experiments rises in plasma FFA concentrations comparable to those seen with systemic infusion of $1 \mu \mathrm{g}$ per $\mathrm{kg}$ per minute were seen, presumably because some of the infused norepinephrine escaped inactivation during the first passage through the liver. One of these animals (Dog O, Table I) showed a rise in liver triglyceride concentration, but the second animal (Dog N, Table I) failed to show any change in liver triglyceride concentration. It should be noted that both animals given the high rate of norepinephrine infusion intraportally died, for reasons unknown, within 6 hours after completion of the experiment.

Fatty acid composition of liver lipids, plasma FFA and adipose tissue before infusion of nor- 


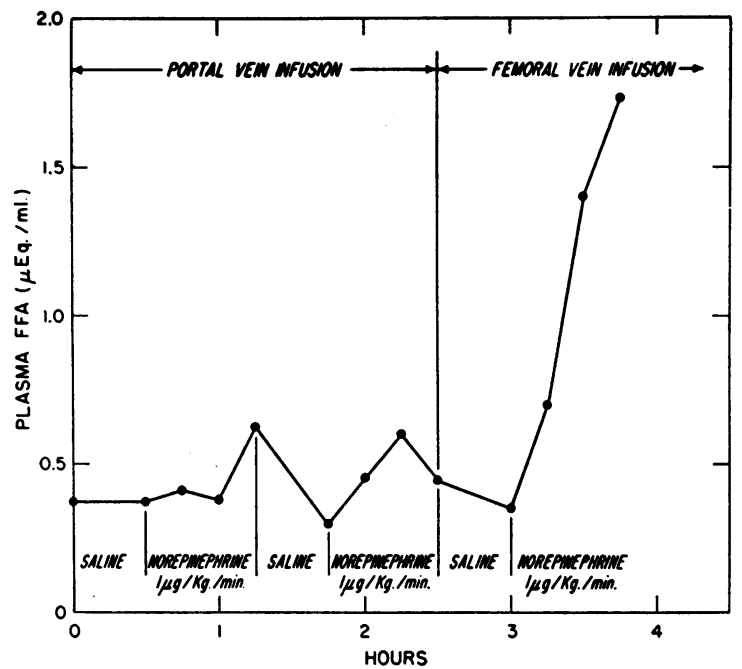

Fig. 5. Comparison in the SAME ANimal of plasma FFA RESPONSE TO NOREPINEPHRINE INFUSION VIA THE PORTAL VEIN IN TWO SUCCESSIVE 45-MINUTE PERIODS, INTERRUPTED BY SALINE INFUSIONS, WITH PLASMA FFA RESPONSES TO THE SAME RATE OF NOREPINEPHRINE INFUSION DELIVERED VIA FEMORAL VEIN.

epinephrine, and of liver lipids and plasma FFA after infusion. In experiment $\mathrm{F}$ (see Table I and Figure 4), the fatty acid compositions of the liver lipid fractions, plasma FFA and adipose tissue were determined and are shown in Figure 7. While the triglyceride content of the liver increased from 3 to $39 \mathrm{mg}$ per $\mathrm{g}$ liver, the decrease in linoleic acid at the end of 8 hours was only 18 per cent. That linoleic acid was not contributed

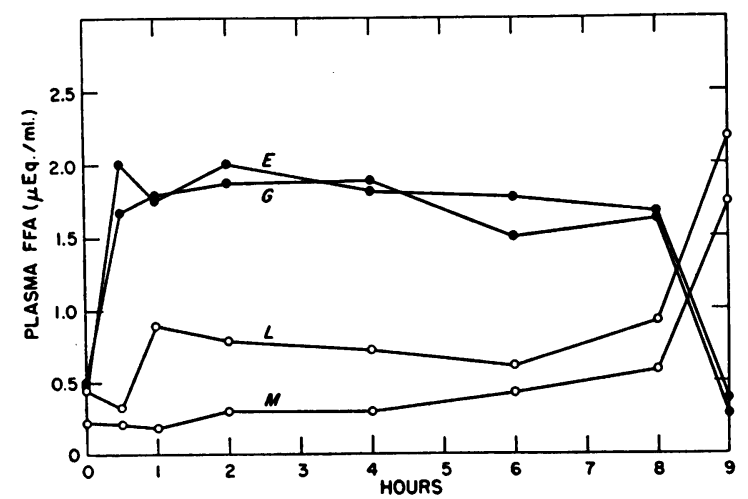

Fig. 6. Comparison between plasma FFA responses IN TWO ANIMALS RECEIVING NOREPINEPHRINE VIA THE FEMORAL VEIN (-—) AND THE PLASMA FFA RESPONSES IN TWO ANIMALS RECEIVING THE SAME RATE OF NOREPINEPHRINE INFUSION VIA THE PORTAL VEIN $(\mathrm{O}-\mathrm{O})$. The letters on each curve correspond to the same letters in Table I, which shows the corresponding liver lipid changes.

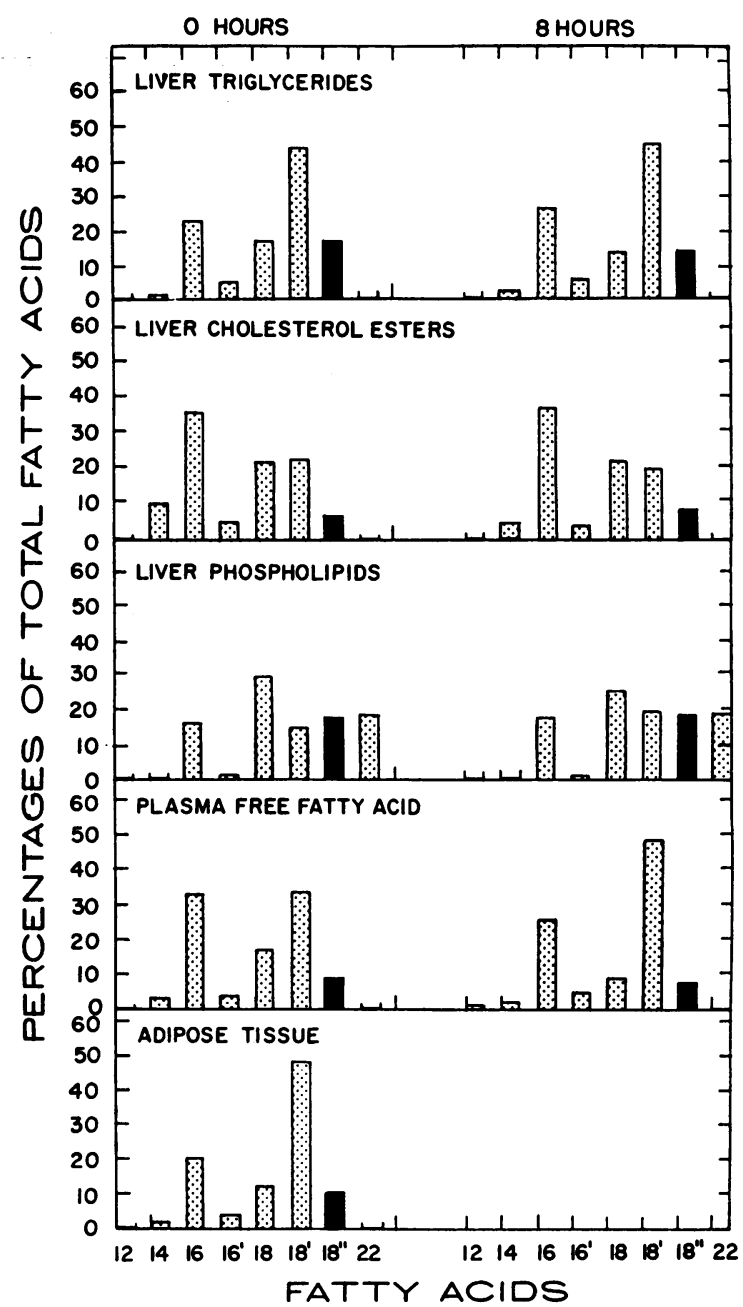

Fig. 7. FatTy acid composition of adipose tissue, PLASMA FFA AND LIVER LIPID FRACTIONS AT ZERO TIME (LEFT) AND OF PLASMA FFA AND LIVER LIPID FRACTIONS AFTER 8 HOURS OF NOREPINEPHRINE INFUSION (RIGHT).

to triglyceride by transfer from phospholipid or cholesterol esters is apparent from examination of Table I and Figure 7. First, the absolute concentration of these fractions actually increased slightly, and second, the per cent linoleic acid in them, rather than decreasing, increased somewhat over zero time values. The fatty acid composition of the liver triglycerides, before and after norepinephrine, was similar to the composition of the fatty acids of adipose tissue as determined in a biopsy specimen taken from the mesenteric fat. The fatty acid composition of the plasma FFA after norepinephrine infusion also became almost identical to the composition of the adipose tissue triglycerides. 


\section{DISCUSSION}

These experiments demonstrate that a sustained elevation of plasma FFA concentration, induced in this case by constant intravenous infusion of norepinephrine, is associated with a progressive, rapid increase in the level of triglycerides in the liver. The latter effect is related to either: 1) the elevated FFA concentration in the plasma and saturation of the normal mechanism for handling FFA by the liver, 2) liver damage from the experimental procedure in which the normal mechanism for handling FFA by the liver was compromised, 3) a direct or indirect effect of norepinephrine on the liver, or 4) a combination of any of the possibilities noted above. That the fatty liver was not caused by a direct effect of norepinephrine on liver metabolism is demonstrated by the portal vein infusion experiments in which norepinephrine failed to affect liver triglycerides except when plasma FFA was also affected. The possibility that the vasomotor effects of norepinephrine on hepatic circulation may have played a role in the development of the fatty liver cannot be ruled out by these experiments. That the experimental procedure, per se, independent of the norepinephrine effect, may have significantly damaged the liver seems unlikely, since no histopathological changes were noted in the livers of control animals and because of the highly significant differences in liver triglyceride observed between control and experimental animals. However, the possibility that the experimental procedure may have, in some unknown manner, restricted the normal capacity of the liver to handle FFA cannot be excluded.

The study of the fatty acid composition of the newly deposited triglycerides helps establish that they were not synthesized by the liver de novo, since the linoleic acid content increased in proportion to the over-all increase in triglyceride fatty acids (25). It has been shown that linoleic acid is not synthesized by mammalian liver (26) and rats, in particular, can be made deficient in linoleic acid (27). The fact that the proportion of linoleic acid in the hepatic triglycerides remains the same despite a large increase in the total hepatic triglycerides does not prove that all of the fatty acids are derived from the periphery under the influence of norepinephrine, but does prove that the fraction of fatty acids derived from the periphery probably remains the same under the in- fluence of the hormone as in control conditions. Furthermore, the pattern of the plasma FFA during the infusion of norepinephrine was altered so as to become almost identical with the pattern of fatty acids in the adipose tissue and strikingly similar to the fatty acid pattern of the newly formed hepatic triglycerides. These results seem to justify the hypothesis that the most probable sequence of events is the following: mobilization of fatty acids from adipose tissue by norepinephrine, transport to the liver, and incorporation into liver triglycerides.

It has been established that an intact adrenal gland is essential for the production of certain kinds of fatty liver. This is true for the fatty liver due to phosphorus poisoning (1), prolonged fasting (2), exposure to cold (2), treatment with ethionine (3), and treatment with epinephrine (4). Recently it was shown directly that the ability of the animal to mobilize fatty acids from adipose tissue in response to epinephrine stimulation likewise depends upon the adrenal gland $(28,29)$ and possibly the pituitary gland $(30)$ as well. It was suggested that the failure to induce fatty liver in the absence of the adrenal gland might be a reflection of this decreased ability of adipose tissue to respond in the animal with adrenocortical insufficiency. Also, it has been shown that adrenergic blocking agents inhibit the epinephrine-induced release of FFA from adipose tissue in vitro (31), and that they also reduce the triglyceride deposition in normal rat livers induced by carbon tetrachloride, ethionine and ethanol (25).

Putting the present studies into the context of available information concerning development of fatty liver, it is theoretically possible to propose two general categories, as indicated in Figure 8. On the one hand, fatty liver can be produced in the absence of hepatic damage if the rate at which fatty acids are brought to a normal liver exceeds its ability to metabolize them further, either by oxidation or by resecretion into the plasma as components of the lipoproteins. In the present experiments, there is no reason to believe that the liver was in any way damaged, unless the anesthesia or the surgical manipulation induced temporary derangement of function. On the other hand, when the liver is damaged or metabolically altered, there may be an inability to handle even 

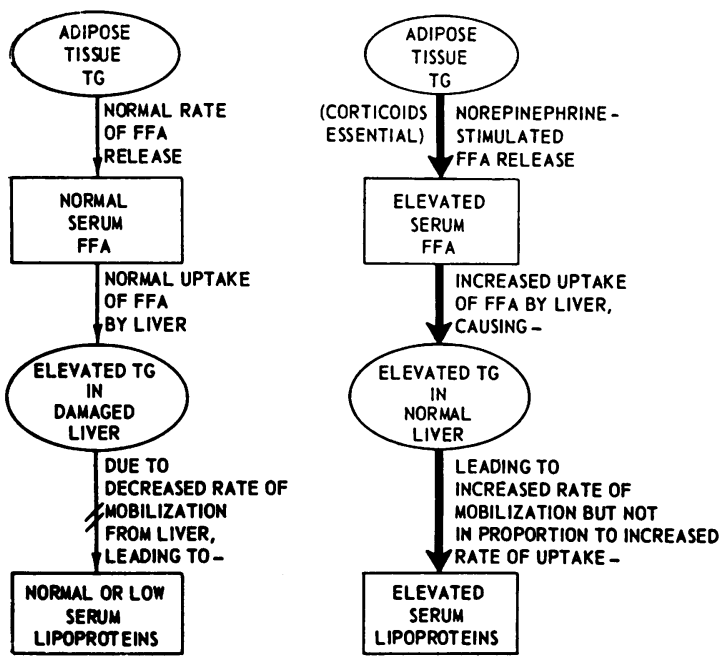

Fig. 8. Proposed scheme summarizing the role of PLASMA FFA IN THE DEVELOPMENT OF FATTY LIVER IN A NORMAL LIVER (RIGHT) AND IN A DAMAGED OR METABOLICALLY ALTERED LIVER (LEFT). Mobilization, as used in this scheme, includes oxidation to $\mathrm{CO}_{2}$ or secretion into the plasma as component lipids of the lipoproteins, or both.

the normal flow of FFA from the depot. Hepatotoxic agents, such as carbon tetrachloride, may reduce the capacity of the liver to form and secrete lipoproteins or to oxidize fatty acids and thus lead to accumulation of liver fat. In some instances, of course, the fatty liver may be due to a combination of these circumstances, i.e., an increased rate of delivery of fatty acids to the liver and a decreased ability of the liver to handle them. This is not meant to imply that all fatty livers can be explained on this simple basis. For example, there is evidence to suggest that the fatty liver due to ingestion of alcohol may in part be the result of increased rates of fatty acid synthesis in the liver (32). However, the accumulated evidence supporting the importance of transport of fat from depot to liver, presumably as FFA, in the development of fatty liver from many causes is impressive.

\section{SUM MARY}

Sustained elevation of plasma FFA concentration in dogs, induced by infusion of norepinephrine into the femoral vein, was associated with a progressive and rapid rise in liver triglyceride. The same concentration of norepinephrine infused into the portal vein caused little elevation of plasma FFA and no rise in liver triglyceride. Studies of the fatty acid composition of the liver triglyceride, plasma FFA and adipose tissue triglyceride were consistent with the hypothesis that the newly formed liver triglyceride was synthesized from plasma FFA mobilized from adipose tissue. The role of plasma FFA in the development of fatty liver is discussed, and a scheme for the development of fatty liver under a variety of conditions is presented.

\section{REFERENCES}

1. Verzar, F., and Laszt, L. Nebennierenrinde und Fettwanderung. Biochem. Z. 1936, 288, 356.

2. LeBlond, C. P., Thoai, Nguyen-van, and Segal, G. Infiltration graisseuse du foie sous l'action des agents nocifs. C. R. Soc. Biol. (Paris) 1939, 130, 1557.

3. Wool, I. G., and Goldstein, M. S. Role of neurohumors in the action of the adrenal cortical steroids : Mobilization of fat. Amer. J. Physiol. 1953, 175, 303.

4. MacKay, E. M. Influence of adrenalectomy on liver fat as varied by diet and other factors. Amer. J. Physiol. 1937, 120, 361.

5. Barrett, H. M., Best, C. H., and Ridout, J. H. A study of the source of liver fat using deuterium as an indicator. J. Physiol. (Lond.) 1938, 93, 367.

6. Levin, L., and Farber, R. K. Hormonal factors which regulate the mobilization of depot fat to the liver. Recent Progr. Hormone Res. 1952, 7, 399.

7. Gordon, R. S., Jr. Unesterified fatty acid in human blood plasma. II. The transport function of unesterified fatty acid. J. clin. Invest. 1957, 36, 810.

8. Fredrickson, D. S., and Gordon, R. S., Jr. Transport of fatty acids. Physiol. Rev. 1958, 38, 585.

9. Dole, V. P. A relation between non-esterified fatty acids in plasma and the metabolism of glucose. J. clin. Invest. 1956, 35, 150.

10. Trout, D. L., Estes, E. H., Jr., and Friedberg, S. J. Titration of free fatty acids of plasma: A study of current methods and a new modification. J. Lip. Res. 1960, 1, 199.

11. Gordon, R. S., Jr., and Cherkes, A. Production of unesterified fatty acids from isolated rat adipose tissue incubated in vitro. Proc. Soc. exp. Biol. (N. Y.) 1957, 97, 150.

12. Gordon, R. S., Jr., and Cherkes, A. Unesterified fatty acid in human blood plasma. J. clin. Invest. 1956, 35, 206.

13. Havel, R. J., and Goldfien, A. The role of the sympathetic nervous system in the metabolism of free fatty acids. J. Lip. Res. 1959, 1, 102.

14. White, J. E., and Engel, F. L. A lipolytic action of epinephrine and norepinephrine on rat adipose tissue in vitro. Proc. Soc. exp. Biol. (N. Y.) 1958, 99, 375 . 
15. Sperry, W. M., and Webb, M. A revision of the Schoenheimer-Sperry method for cholesterol determination. J. biol. Chem. 1950, 187, 97.

16. Stewart, C. P., and Hendry, E. B. The phospholipids of blood. Biochem. J. 1935, 29, 1683.

17. Bragdon, J. H. Colorimetric determination of blood lipides. J. biol. Chem. 1951, 190, 513.

18. Nelson, N. A photometric adaptation of the Somogyi method for the determination of glucose. J. biol. Chem. 1944, 153, 375.

19. Borgstrom, B. Investigation on lipid separation methods. Separation of phospholipids from neutral fat and fatty acids. Acta physiol. scand. 1952, 25, 101.

20. Karmen, A. Unpublished results.

21. Lovelock, J. E. A sensitive detector for gas chromatography. J. Chromat. 1958, 1, 35.

22. Ellis, S. The metabolic effects of epinephrine and related amines. Pharmacol. Rev. 1956, 8, 485.

23. Shafrir, E., Sussman, K. E., and Steinberg, D. The nature of the epinephrine-induced hyperlipidemia in dogs and its modification by glucose. J. Lip. Res. 1959, 1, 109.

24. Lund, A. Elimination of adrenaline and noradrenaline from the organism. Acta pharmacol. (Kbh.) 1951, 7, 297.

25. Maling, H. M., Horning, M. G., Butler, W. M., Jr., Highman, B., and Brodie, B. B. Triglyceride deposition in rat liver through derangement of fat transport by various chemical agents. Fed. Proc. 1960, 19, 229.

26. Bernhard, K., and Schoenheimer, R. The inertia of highly unsaturated fatty acids in the animal, investigated with deuterium. J. biol. Chem. 1940, 133, 707.

27. Burr, G. O. Significance of the essential fatty acids. Fed. Proc. 1942, 1, 224.

28. Shafrir, E., and Steinberg, D. The essential role of the adrenal cortex in the response of plasma free fatty acids, cholesterol, and phospholipids to epinephrine injection. J. clin. Invest. 1960, 39, 310.

29. Reshef, L., and Shapiro, B. Effect of epinephrine, cortisone and growth hormone on release of unesterified fatty acids by adipose tissue in vitro. Metabolism 1960, 9, 551.

30. Goodman, H. M., and Knobil, E. Mobilization of fatty acids by epinephrine in normal and hypophysectomized rhesus monkeys. Proc. Soc. exp. Biol. (N. Y.) 1959, 100, 195.

31. Schotz, M. C., and Page, I. H. Effect of adrenergic blocking agents on the release of free fatty acids from rat adipose tissue. J. Lip. Res. 1960, 1, 466.

32. Lieber, C. S., and Schmid, R. The effect of ethanol on fatty acid metabolism; stimulation of hepatic fatty acid synthesis in vitro. J. clin. Invest. 1961, 40, 394. 